\title{
Litotic/Hyperbolic Paradigm in the Igbo Language: Preliminary Analysis
}

\author{
Ugochukwu D. Mbagwu, Cecilia A. Eme, Linda C. Nkamigbo, Greg O. Obiamalu \\ Department of Linguistics, Nnamdi Azikiwe University, Awka, Nigeria \\ Email:mbagwu2002@yahoo.com,mrsceciliaeme@yahoo.com,linkamigbo@gmail.com, \\ go.obiamalu@unizik.edu.ng
}

Received 2 April 2016; accepted 24 May 2016; published 27 May 2016

Copyright (C) 2016 by authors and Scientific Research Publishing Inc. This work is licensed under the Creative Commons Attribution International License (CC BY). http://creativecommons.org/licenses/by/4.0/ (c) (7) Open Access

\begin{abstract}
Litotes is understatement while hyperbole is overstatement. Litotes is linguistically characterized by a negative. However, by context of use it contributes to a positive output. Hyperbole is not characterized by any specific linguistic elements; words are used to express situations beyond reality. The litotic and hyperbolic phenomena receive more literary stylistic than linguistic or pragmalinguistic attention. In this paper, we provide some morphological/syntactic evidence in Igbo that gives strong indication that the litotic and hyperbolic relations are encoded in the language; hence could be accounted for linguistically or pragmalinguistically. We identify that the morphemes, -gbu "kill" and -rụ "corrupt" mark the relations. These morphemes could be free and in some cases appear as bound morphemes (i.e., affixes, particularly suffixes). In such cases as suffixes they serve to express the litotic or hyperbolic relations. They express the litotic relation when they modify a state of affairs in which excessiveness may have a positive implication. Hence, the negative implication of the suffixes does not cancel the significance of what is stated but concludes to asserting it positively. On the other hand, they express the hyperbolic relation when they modify an action about which excessiveness is negative. Here, they are evidently degree markers. They express the degree of what is denoted usually out of normal proportion. We readily see that the suffixes express the litotic relation with stative verbs while they express the hyperbolic relation with dynamic verbs. Beyond this linguistic fact, we note that their use is context-sensitive; and, this paper demonstrates the contexts implicit in their use.
\end{abstract}

\section{Keywords}

Litotes, Hyperbole, Pragmalinguistics

\section{Introduction}

Litotes and hyperbole are figures of speech or a part of the features of figurative language. For Harris, figurative

How to cite this paper: Mbagwu, U.D., Eme, C.A., Nkamigbo, L.C. and Obiamalu, G.O. (2016). Litotic/Hyperbolic Paradigm in the Igbo Language: Preliminary Analysis. Open Journal of Modern Linguistics, 6, 161-166.

http://dx.doi.org/10.4236/ojml.2016.63016 
language is language that communicates ideas beyond the ordinary meanings of the words. That is, litotes and hyperbole are utterances whose linguistic constituents are not analyzable by their conventional semantic notions.

Litotes and hyperbole are opposites, while litotes is an understatement, hyperbole is an overstatement. Of course, the understatement or overstatement is for a goal of expression. The understatement usually anticipates a positive evaluation of the reference while the overstatement is basically implicit of emphasis. Examples of litotes in English show that it is linguistically characterized by a negative. The negative marks the understatement. However, it analyzes to an affirmative. The hyperbole may not be described with any peculiar linguistic features. What is particular about it is that a condition, situation, state or act is expressed beyond the limits of what is acceptable or known to be acceptable, of course, as already pointed out, to emphasize that condition, situation, state or act.

As figures of speech, litotes and hyperbole have applied more commonly in stylistic analysis of literary works, especially poetry. There is not, as much as we know, any linguistic attention or pragmalinguistic attention given to them. This is not expected anyway being that they are figures of speech. However, it is interesting to note here that we have observed structures illustrating the notions of litotes and hyperbole in the Igbo language. In other words, the notions are encoded into the structure of the language and would not be described as an innovative feature manifesting in the use of the language. Yes, it is possible that diachronically they would have been innovative but we are more interested in their synchronic value. In this value, we acknowledge that it is context-based. Being that linguistics does not emphasize context in the analysis of language, pragmatics hereby applies. Below, we try to make a distinction between linguistics and pragmatics with a view to providing some explication of context as it would be involved in the analysis of the data here.

\section{Linguistics versus Pragmatics}

Linguistics is the study of language with the basic objective to describe its structure. The rules that build the structure are referred to as grammar. In other words, linguistics studies the grammar of language. It emphasizes the speakers' knowledge of the micro-structure of their language. This is the knowledge of the phonology, morphology, syntax and semantics of the language (cf. Ndimele, 1996: p. 3). This knowledge is innate. Hence, the Chomskyian distinction between i-language (internalized language) and e-language (externalized language). All of the linguistic enterprise is to account for the knowledge and not to account for how the knowledge is engaged in the use of language. Separating language from use has proved difficult since the essence of language is in communication and communication involves interaction, which is functionally the use of language. To emphasize the inseparability between language and its use pragmatics has emerged. Since its emergence, a good number of language issues which linguistics either avoided or idealized have received clearer descriptions. This is the indication that pragmatics complements Linguistics. Leech (1983: p. 6) demonstrates this in his three-way structuring of the relationship between pragmatics and semantics (the branch of Linguistics closest to Pragmatics): semanticism (pragmatics inside semantics), pragmaticism (semantics inside pragmatics) and complementarism (pragmatics and semantics complement each other but are otherwise independent areas...)

Leech's semanticism is pragmatics inside semantics. This is best illustrated with the word, "promise”. The uttering of the word does not always express its semantic notion. That is, the meaning of the word is not bound by the limits of its dictionary specifications. The meaning includes “active pragmatic character” (cf. Mey, 2001: p. 7). Pragmaticism, on the contrary, is the effects the word as uttered has. Definitely, the effects are not a part of the semantics. What is implicit here is that users do things with words: that is, they use words to do things they intend and this is never outside a context. Evident in the notation of semanticism and pragmaticism is complementarism: semantics and pragmatics complement each other even as they pursue independent goals. This position is more appropriately captured by Levinson (1983: p. 15):

From what we know about the nature of meaning, a hybrid or modular account seems inescapable; there remains the hope that with two components, a semantics and a pragmatics working in tandem, each can be built on relatively homogenous and systematic lines.

From the foregoing, the more general definitions of pragmatics are implicit. Wepresent two which we apply to this study: "the study of those relations between language and context that are grammaticalized, or encoded in the structure of a language" (Levinson, 1983: pp. 2-3) and "the study of the use of language in human communication as determined by the conditions of society” (Mey, 2001: p. 5). 
The definitions emphasize the relation between language and context. While Levison calls attention to the context that is encoded in language, Mey brings into focus the context as created and effected by society. Mbagwu (2015) draws from this in distinguishing two types of context: grammaticalized context (which Levison emphasizes) and non-grammaticalized context which is implicit in Mey's definition. A feature of language that demonstrates grammaticalized context is deixis. Grundy (2008: p. 18) uses (1) to illustrate deixis:

\section{(1) I'm here now}

Grundy explains that this sentence has the quality of indeterminacy which is dissolved by contextual factors, who (the speaker), where (place of utterance) and when (time of utterance). He comments,

This indeterminacy stems from the speaker's use of the words "I", "here" and "now". Although the meaning of the word $I$ is perfectly clear and not at all problematical, the reference that is effected each time it is uttered clearly depends on who utters it. In this respect $I$ is a quite different kind of description for Agatha Christie, which always refers to the same person. Just the same point could be made about here. Its meaning is clear enough but its reference depends on the location of the speaker when the sentence is uttered, so that here might refer to Durham or Durban or Marks and Spencer or the speaker's kitchen. Similarly the reference of now is determined by the time at which the sentence is spoken.

The point here is that the words, "I", "here" and "now" are examples of some of the words found in English that are interpreted by reference to the context in which they are used. For the context to be the interpreting factor of the words is the indication that they encode the context, hence the context is grammaticalized. The opposite of the grammaticalized context is non-grammaticalized context, which describes the manipulation of language with context to achieve intentions. Let us consider the following analogy as given by Grundy op cit,

... if I had heard that a relative had been injured and taken to hospital, I might race there as quickly as possible and say on arrival "I'm here now", which would count perhaps as a comforting assurance. On the hand, if I get home from work and see my children larking about instead of getting on with their homework and say "I'm here now", it counts as a stern warning. Or if I were to arrive late for a meeting and knew that I had kept my colleagues waiting, uttering "I'm here now" might count as an apology or a signal to start the meeting.

We see more clearly here that while there are some cases in which context is encoded into language, there are some other cases in which context is applied to manipulate language to express one thing or the other. It is interesting to note that even the words in a language that encode particular contexts are not immune to contextual manipulation. Grundy's analogy is implicit of this.

In the next section, we present morphological/syntactic evidence in Igbo that gives strong indication that the litotic and hyperbolic relations are encoded in the language. Of course, as we have pointed out, this does not mean that the structures are not products of contextual manipulation of words to achieve intentions.

\section{Litotic and Hyperbolic Paradigm in Igbo}

We identify that the morphemes, -gbu "kill” and -rụ "corrupt” mark the litotic and hyperbolic paradigm in Igbo. These morphemes by morphological/syntactic analysis are verbs:

(2) a. Òbí gbù-rù éké Obi kill-PAST python

'Obi killed a python'

b. Àdá rụ̀-rụ̀ àrụ́

Ada be.corrupt-APP corruption

'Ada is defiled'

As (2a \& b) shows, while the "gbu" is dynamic, "rụ" is stative. These two verbs have been observed in some structures to occur as a second element in what we prefer to call here a verbal complex. We use our verbal complex to subsume Mbah's (1999: p. 138) complex verbs and compound verbs. We note that Mbah's complex verbs are verbs that add at least one affix while the compound verbs contain at least two independent simple verbs; (3 - 4) illustrates this respectively. 

(3) a. bàtá 'come in'
b. gòté 'buy for'
(4) a. gbábà 'run into'
b. kóbà 'pluck into'

We justify our position by the fact that the second element, whether an affix or a verb, translates into a prepositional notion. Of course, this possibility compels Mbah (1999: pp. 176-182; 2010) to classify verbs of (4) and their likes as "category incorporating preposition", that is, the verbs incorporate a prepositional notion. The prepositional notion, it is important to note, surfaces as an output of semantic analysis of the succeeding verb into the preceding one:

(5) Òbí gbá-bà-rà n'ụ́lọ

Obi run-enter-PAST in house

'Obi ran into the house'

This is what applies to the "-gbu" and "-rụ" when they appear as the second constituent in a verbal complex. However, we could not conclude to the prepositional notion denoted. What we perceive and so we posit is a "degree" notion. Moreover, even though it is a subject of another discussion, there are verbal complexes in which the second verb element does not encode a prepositional notion, a degree notion (such as we have concluded for -gbu/-rụ) or any other notion. Such complexes describe the true compounds:

(6) a. Àdá tú-fù-rù ákwụ́kwọ́

Ada throw-get lost-PAST book

'Ada lost a book'

b. Àdá tì-wà-rà éféré

Ada strike-break-PAST plate

'Ada broke a plate'

As it is evident, the two verb elements express actions that conclude to an action, which is usually the action denoted by second element. We therefore formalize verb complexes as follows:

(7) a. V + ES (Extensional suffix)

b. V + V-PN/DN/ONs (Verbs implicit of a Prepositional, Degree or other notions)

c. $\mathrm{V}+\mathrm{V}$

In this paper, (7b) applies.

(8) a. Àdá gbà-gbù-rù ònwé yā n'ọsọ́

Ada run-kill-APP self her in race

'Ada runs too much/faster than is ordinary'

b. Àdá mà-gbù-rù ò̀nwé yā ná ḿmā

Ada be beautiful- kill-APP self her in beauty

'Ada is extremely beautiful'

(9) a. Ńrí à tọ̀-rụ̀-rụ̀ àlà

food this be sweet-corrupt-APP ground

'This food is excessively or extremely delicious'

b. Ḿmányá ǹké à tọ̀-rụ̀-rụ̀ àlà

wine particular this be sweet-corrupt-APP ground

'This particular wine is excessively sweet'

We point out here that by context of use in which the litotic and hyperbolic paradigm is exemplified -rụ is a variant of -gbu. However, it restrictively expresses state and occurs with verbs of similar expressive capacity. 
Consider (10).

(10) a. Àdá rì-gbù-rù ònwé yā ná ńrí Ada eat-kill-APP self her in food

'Ada eats excessively'

b. ? Àdá rì-rụ̀-rụ̀ à̀à

Ada eat-corrupt-APP ground

c. Àdá mà-rụu-rụ̀ àlà

Ada be beautiful-corrupt-APP ground

'Ada is excessively beautiful'

It is not clear why (10b) which ought to be another way of expressing (10a) is unacceptable while (10c) and (8b) that express the same meaning are acceptable.

We recall that litotes is understatement while hyperbole is overstatement. The data examples already presented illustrate more clearly overstatement. That is, -gbu and -rụ are more hyperbolic than litotic. We have here applied the description of litotes as identified in English, which includes a negative but does not realize the negative in the output of its expression.

(11) The girl is not bad

In this sentence, the beauty of the girl is understated with a negative to express that the girl is beautiful. Even though, -gbu or -rụ in (8b) and (9c) are not negatives by morphological or syntactic analysis, we analyze them as negative by recourse to the implication of "death" and "corruption" which they denote respectively. In fact, it is negative that someone is beautiful unto death or corruption. The interesting thing here is the negativity realizes the expression of astonishing or stunning beauty, which is positive. Upon this premise, we present -gbu and -rụ as litotic. Of course, in being litotic, they modify a state of affairs or an action in which excessiveness has a positive implication. In other words, the negative implication of these suffixal elements does not cancel the significance of what is stated but concludes to asserting it positively. On the other hand, -gbu expresses the hyperbolic relation when it modifies an action in which excessiveness is negative. In other words, the -gbu of (8a \& b) and the -rụ of (9a \& b) are litotic but the -gbu in (12) is hyperbolic.

(12) Òbí nụ̣-gbù-rù ònwé yā ná ḿmányá

Obi drink.kill-APP self him in wine

'Obi drinks excessively'

Obi does not die from drinking excessively. It is an exaggeration of how much Obi drinks or drank. But, for (8a \& b; 9a \& b), compliments are evident.

Context distinguishes between the litotic -gbu and the hyperbolic -gbu. The litotic -gbu applies to intensify a quality, even though excessively, but to express a compliment. The focus of compliment de-emphasizes the degree notion. The hyperbolic -gbu does not have the focus of compliment. Hence, it emphasizes the degree to which an action has been performed.

As evident in (12), even though the degree expressed is beyond the limits of what is ordinary or normal, the communicative goal focuses on emphasizing that degree. By this, we present the hyperbolic -gbu as clearly a degree-marker but this is not the case in all of its occurrences. For instance, a context of use is possible to give (8a) and (12) the interpretation of someone running or drinking (so much), following which action, they die. Here, -gbu is not litotic or hyperbolic. In other words, context distinguishes between litotic and hyperbolic -gbu and non-litotic and hyperbolic -gbu.

Notice that we have used "so much" in brackets to express two dimensions of a context: someone could die running or drinking not as result of doing too much of it and it is possible for someone to run or drink so much that the running or drinking becomes the immediate cause of the person's death.

We present below a Table 1 that illustrates the -gbu/-rụ litotic and hyperbolic paradigm.

The table provides a summary of the paradigm as we have tried to explain. 
Table 1. The -gbu/-rụ Litotic and hyperbolic paradigm.

\begin{tabular}{|c|c|c|c|c|c|}
\hline Litotic -gbu/-rụ & +Excess & +Compliment & -Degree & +Dynamic & + Stative \\
\hline Hyperbolic -gbu & +Excess & -Compliment & +Degree & +Dynamic & -Stative \\
\hline
\end{tabular}

\section{Conclusion}

We see that -gbu and -rụ are lexical verbs but in the verbal complexes in which they occur as litotic or hyperbolic markers, they surface as suffixes. As suffixes they express the degree notion. This degree notion is characterized by excessiveness. However, the excessiveness of the litotic -gbu/-rụ has what we have called focus of compliment. We have argued that the focus of compliment de-emphasizes degree. For the hyperbolic -gbu, there is no focus of compliment. It emphasizes degree and we have analyzed it as clearly a degree marker, even though, it expresses the degree of beyond what is normal proportion.

The features [+Excess] and $[ \pm$ Compliment] are context-based. Between the two, $[ \pm$ Compliment] distinguishes the litotic -gbu/-rụ from the hyperbolic -gbu. It is also this feature that marks the distinction between the the litotic/hyperbolic -gbu and the non-litotic/hyperbolic -gbu. These context-based features are determined with the elements. Hence, we analyze the elements as encoding them.

We believe that there are more dimensions to our positions about the litotic/hyperbolic paradigm in Igbo. Further studies would address the dimensions. Beyond this, we have succeeded at least in calling attention to this paradigm. With this attention, we anticipate that in line with the thrust here other languages would be studied to provide more information about the phenomenon.

\section{Note}

Our use of the grammatical notation, APP (applicative) is irregular with the standard usage. We have used it here in the sense of Emenanjo (1978: p. 119) even though there is some disparity. For Emenanjo, it expresses the prepositional notion of "to/for" as in "to/for one's benefit or good". This is what we have taken it to be here except that with the hyperbolic, such computation would be controversial.

\section{References}

Emenanjo, N. (1978). Elements of Modern Igbo Grammar: A Descriptive Approach. Ibadan: University Press Ltd.

Grundy, P. (2008). Doing Pragmatics. London: Hodder Education.

Leech, G. N. (1983). Principles of Pragmatics. London: Longman.

Levinson, S. C. (1983). Pragmatics. Cambridge: Cambridge University Press.

Mbagwu, D. U. (2015). Pragmatics in Prose Fiction. In R. I. Okorji, C. A. Eme, \& G. S. Omachonu (Eds.), Contemporary Issues in Linguistics and Languages: A Festchrift in Honour of Prof. Clara Ikekeonwu at 65 (pp. 378-388). Enugu: Rossen Publications Ltd.

Mbah, B. M. (1999). Studies in Igbo Syntax: Igbo Phrase Structure. Nsukka: Prize Publishers.

Mbah, B. M. (2010). Category Incorporated Preposition in Igbo. In C. Uchechukwu, \& B. M. Mbah (Eds.), The Preposition in Igbo (pp. 26-45). Onitsha: Edumail Publications.

Mey, J. L. (2001). Pragmatics: An Introduction. Malden: Blackwell Publishing.

Ndimele, O.-M. (1996). An Advanced English Grammar \& Usage. Aba: Nigerian Institute for Nigerian Languages. 